\title{
The Effect of Submergence on the Distribution of Some Trace Elements within the Recent Sediments at Mosul Lake
}

\author{
Zeki. A. Aljubouri \\ Department of Geology \\ College of Science \\ University of Mosul
}

Hazim. A. Al-Kawaz Research Center for Environment and Water Resources Mosul University

(Received 21/1/2003, Accepted 1/3/2003)

\section{ABSTRACT}

Sixty five samples were collected from the eastern and western banks of Mosul lake at submergence levels of (305) and (327) (m.a.s.l) and analyzed for ten trace-elements (V, $\mathrm{Co}, \mathrm{Ni}, \mathrm{Cu}, \mathrm{Zn}, \mathrm{Rb}, \mathrm{Sr}, \mathrm{Zr}, \mathrm{Mo}$ and $\mathrm{Pb}$ ).

Four trends of variation in the concentrations of trace elements in the sediments of the lake and at both banks were observed. These are: (a) Increase at both (305) and (327)(m.a.s.l.) levels; the increase being more at the (305) level ( $\mathrm{V}, \mathrm{Co}, \mathrm{Zr}$, and $\mathrm{Pb}$ at the eastern bank). (b) Increase at both levels, the increase being less at (305) level ( $\mathrm{Zn}$ ). (c) Increase at both levels at equal or almost equal amounts, $\mathrm{Ni}, \mathrm{Cu}, \mathrm{Rb}, \mathrm{Mo}, \mathrm{Pb}$ at the western bank) and (d) Decrease at both levels ( $\mathrm{Sr}$ ).

From the trends of variation, it may be envisaged that four factors were affecting the variation in concentrations of these elements within the sediments: dissolution of the relatively soluble mineral phases (carbonates and sulphates); mechanical removal of clay size particles (clay minerals); addition of organic matter and fourthly the slope of the banks.

\footnotetext{
تأثير الاغمار عثى تمزيع العناصر الأرية في الزرواسب الحديثة في بحيرة الموصل

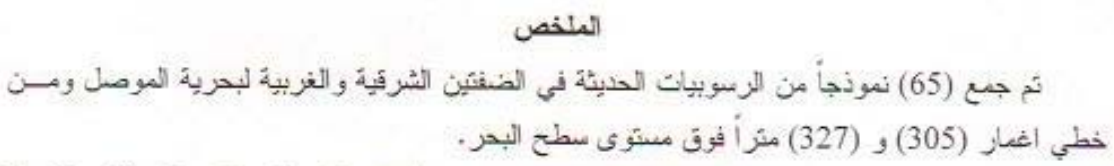

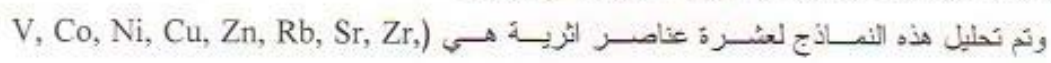

.(Mo and $\mathrm{Pb}$

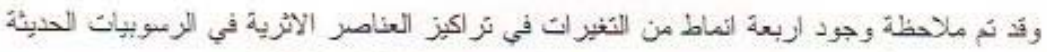

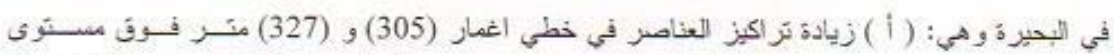

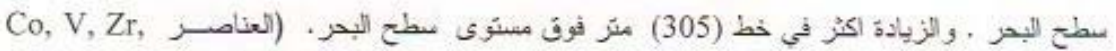
Pb

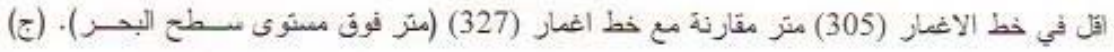




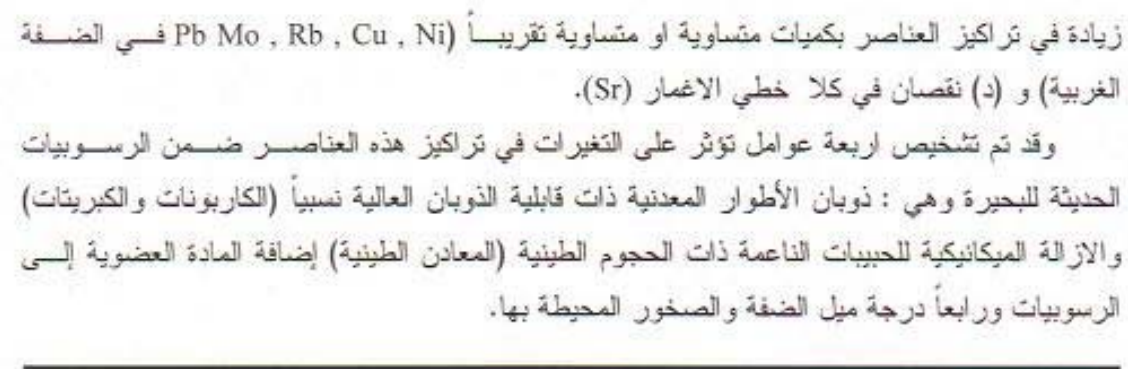

\section{INTRODUCTION}

Mosul lake is the largest reservoir lake on River Tigris. Its maximum storage capacity may exceed (13) billion cubic meters. The surrounding rocks belong to the Fat'ha (Middle Miocene) and Injana (Upper Miocene) Formations.

The Fat'ha Formation consists of repeated cycles of gypsum, marls and carbonates, whereas that of Injana Formation consists of sandstones, marls and conglomerates.

The rocks at the western bank of the lake have a very steep slope which often takes the form of a cliff, cutting through the rocks of Fat'ha Formation. On the other hand, the rocks and sediments of the eastern bank have a relatively gentle slope, not exceeding (30) degrees.

In April, 1987, the water of the lake reached a maximum level of (327) meters above sea-level (m.a.s.l) and stayed at this level for almost six months, then dropped to (315 m.a.s.l) for about (12) months. In November (1988), the level dropped to (303 m.a.s.l) and stayed at this level permanently,

The purpose of this work is to find the concentrations of ten trace elements $(\mathrm{V}, \mathrm{Co}$, $\mathrm{Ni}, \mathrm{Cu}, \mathrm{Zn}, \mathrm{Rb}, \mathrm{Sr}, \mathrm{Mo}, \mathrm{Zr}$ and $\mathrm{Pb}$ ) within recent sediments of the previously submerged (305) and (327) levels at both eastern and western banks of the lake and to compare these concentrations with the unsubmerged part of the lake.

\section{PREVIOUS STUDIES}

Al-Naqib and Al-Taiee (1988) investigated the effects of transported sediments in the north-eastern part of the lake comming from Faida and Buqak valleys. They estimated that these transported sediments make up around $(10 \%)$ of the total dead storage capacity of the lake.

Al-Rawi et al. (1990) investigated the pollution in Duhok valley and its effects on the quality of water in Mosul lake. Al-Kawaz (1991) studied the effects of erosion and the geochemistry and mineralogy of the recent sediments within (305) and (327) submergence levels of the lake. He concluded that the source of most mineral phases of the recent sediments of the lake is from the surrounding Fat'ha and Injana Formation.

\section{METHODOLOGY}

In November, 1988 and after the water level of the lake has dropped to (303 m.a.s.1) (96) samples representing the formerly submerged recent sediments at eastern and western banks of the lake from (305) and (327) levels were collected (Figure 1). 


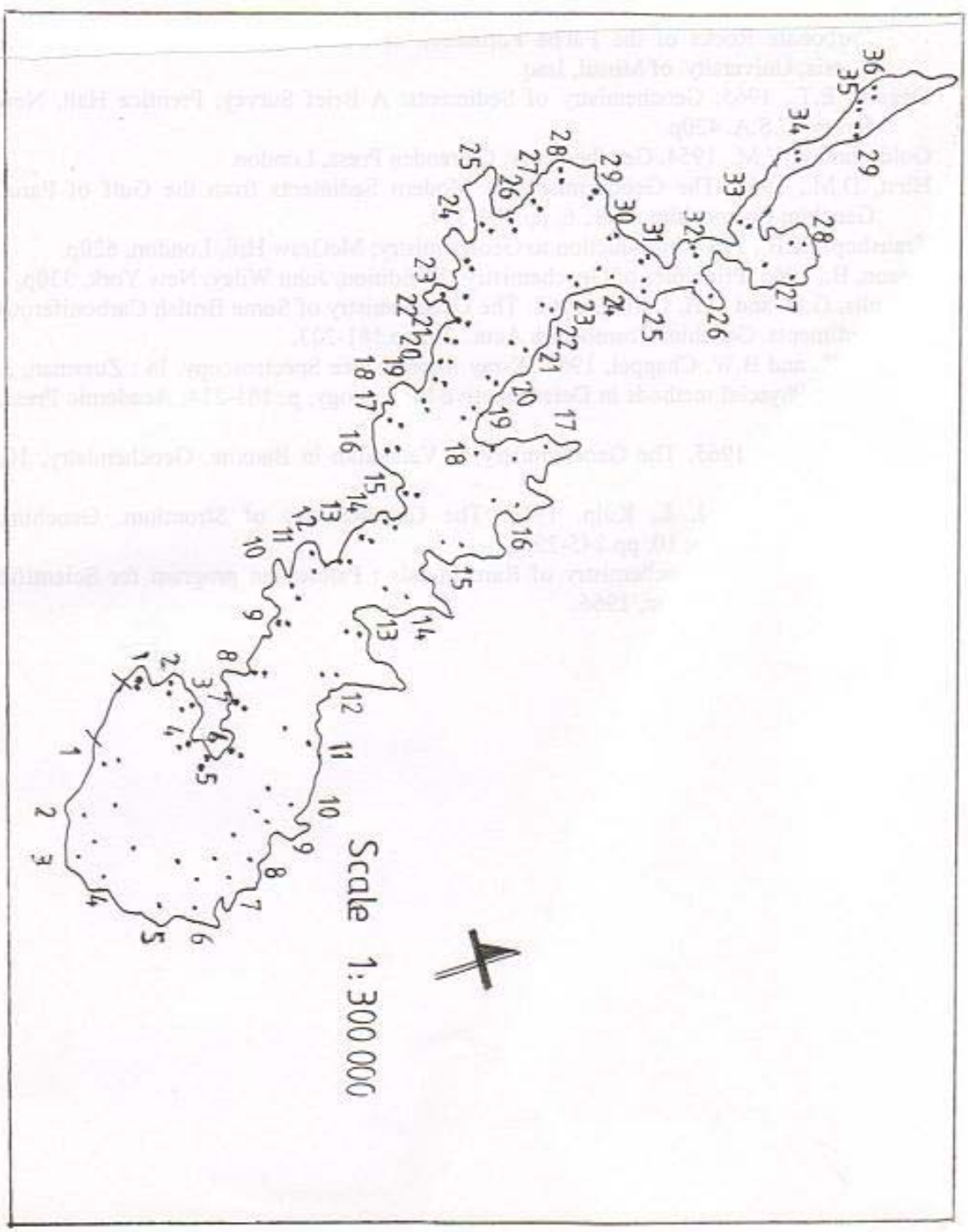

Fig. 1: Mosul lake, with sample location. 
Of these, (65) samples were chosen for analyses, dried, and each sample was divided into three parts. One part was kept as a reference; the second and third were ground and used for mineralogical and geochemical analyses respectively. All analyses were carried out at the geochemical laboratories of the General Company for Geological Survey and Mining, Baghdad, Iraq.

Ten trace elements ( $\mathrm{V}, \mathrm{Co}, \mathrm{Ni}, \mathrm{Cu}, \mathrm{Zn}, \mathrm{Rb}, \mathrm{Sr}, \mathrm{Mo}, \mathrm{Zr}$ and $\mathrm{Pb}$ ) were analyzed using Phillips, XRF Spectrometer. The pellet method of Norrish and Chappel (1967) was applied. The results of analyses are shown in Tables (1,2,3 and 4). Table (5) shows the mean values for the concentrations of trace elements at each submergence level, as well as for the unsubmerged part of the sediments of the lake.

\section{RESULTS and DISCUSSION}

In order to understand the behavior of the studied trace elements during successive submergence of sediments; and in order to explain the variations in concentrations between different elements and variations of the same element at different submergence level, it is very important to know the geochemistry of these elements in sedimentary rocks. A summary of the main distribution of each element is given here after:

Vanadium (V) is mainly concentrated in the organic matter; in the residual fraction and in the clay minerals (Tenyakov, 1965).

Cobalt $(\mathrm{Co})$, nickel $(\mathrm{Ni})$ and copper $(\mathrm{Cu})$ are mainly concentrated in the clay minerals, and in the heavy fraction including the sulphide phase. (Webber and Middleton 1961, Nicholls and Loring 1962, Degens 1965, Aljubouri et al. 1994); Zinc ( $\mathrm{Zn})$ is in dolomite; in clay minerals and in the sulphide phase (Mason, 1966; Aljubouri, 1972).

Rubidium ( $\mathrm{Rb}$ ) is concentrated in the clay minerals (illite); in K-feldspars and in the micas as well as the heavy fraction (Goldschmidt, 1954; Vlasov, 1967; Krauskopf, 1967), Strontium ( $\mathrm{Sr}$ ) is mainly found within the soluble phases (carbonates and sulphates), (Hirst, 1962; Turkian and Kulp, 1965; Aljubouri, 1972).

Zirconium $(\mathrm{Zr})$ is found in the heavy fraction (Hirst, 1962; Al-Ubaidi, 1984). Molybdenum $(\mathrm{Mo})$ and lead $(\mathrm{Pb})$ are concentrated within the heavy fraction including the sulphide phase (Mason, 1966; Krauskopf, 1956; Aljubouri and Sulayman, 1996).

Al-Kawaz (1991) has found that the mineralogy of the submerged and unsubmerged recent sediments of Mosul lake consists mainly of carbonates (dolomite and calcite), quartz and free iron oxides (mainly hematite, $\mathrm{Fe}_{2} \mathrm{O}_{3}$ ) together with the clay minerals (illite, chlorite, kaolinite and motmorillonite).

Because of similarities in mineral phases between recent sediments and the surrounding rocks of the lake. Al-Kawaz (1991) concluded that the source rocks are mainly from the surrounding Fat'ha Formation (Middle Miocene) and to a lesser extent from Injana Formation (Upper Miocene).

It may be envisaged here that the submerged sediments of the lake are subjected to four factors ; these are: dissolution of the soluble mineral phases (calcite and gypsum, then dolomite to a lesser extent); mechanical removal of clay-size particles from sediments and hence accumulation of heavy fraction minerals. Accumulation of organic matter, due to the decay of algae, leading to the formation of organo-metallic complexes, and fourthly the slope of the surrounding rocks and sediments. The lower the slope of the sediments, the more area is exposed to submergence. 
Table 1: Trace Element Analyses (ppm) at Eastern bank, 305 Level (305EA), $(n=15)$.

\begin{tabular}{|l|c|c|c|c|c|c|c|c|c|c|}
\hline & $\mathbf{V}$ & $\mathbf{C o}$ & $\mathbf{N i}$ & $\mathbf{C u}$ & $\mathbf{Z n}$ & $\mathbf{R b}$ & $\mathbf{S r}$ & $\mathbf{Z r}$ & $\mathbf{M o}$ & $\mathbf{P b}$ \\
\hline EA1 & 142 & 11 & 195 & 28 & 53 & 37 & 155 & 166 & 6 & 7 \\
\hline EA2 & 163 & 8 & 50 & 29 & 26 & 24 & 193 & 78 & 5 & 15 \\
\hline EA3 & 180 & 7 & 66 & 25 & 10 & 20 & 231 & 51 & 5 & 6 \\
\hline EA4 & 145 & 8 & 89 & 23 & 22 & 35 & 221 & 83 & 5 & 7 \\
\hline EA5 & 165 & 9 & 208 & 32 & 36 & 36 & 319 & 100 & 5 & 11 \\
\hline EA6 & 220 & 27 & 290 & 29 & 64 & 50 & 210 & 136 & 7 & 7 \\
\hline EA7 & 180 & 21 & 320 & 27 & 72 & 61 & 214 & 168 & 14 & 40 \\
\hline EA8 & 200 & 26 & 230 & 32 & 64 & 48 & 231 & 136 & 7 & 17 \\
\hline EA9 & 210 & 21 & 280 & 36 & 74 & 53 & 214 & 143 & 14 & 49 \\
\hline EA10 & 350 & 8 & 340 & 29 & 74 & 41 & 295 & 92 & 7 & 5 \\
\hline EA11 & 124 & 5 & 110 & 28 & 23 & 64 & 167 & 191 & 6 & 5 \\
\hline EA12 & 220 & 7 & 160 & 33 & 34 & 41 & 284 & 134 & 5 & 32 \\
\hline EA13 & 270 & 7 & 280 & 31 & 43 & 27 & 1013 & 98 & 5 & 68 \\
\hline EA14 & 220 & 5 & 200 & 41 & 30 & 29 & 193 & 30 & 5 & 23 \\
\hline EA15 & 200 & 12 & 250 & 47 & 75 & 51 & 140 & 75 & 5 & 56 \\
\hline
\end{tabular}

Table 2: Trace Element Analyses (ppm) at Eastern Bank, 327 Level, (327EB) of the

\begin{tabular}{|l|c|c|c|c|c|c|c|c|c|c|}
\hline \multicolumn{1}{|c|}{ Lake $(\mathrm{n}=14)$} & $\mathbf{V}$ & $\mathbf{C o}$ & $\mathbf{N i}$ & $\mathbf{C u}$ & $\mathbf{Z n}$ & $\mathbf{R b}$ & $\mathbf{S r}$ & $\mathbf{Z r}$ & $\mathbf{M o}$ & Pb \\
\hline EB16 & 230 & 7 & 205 & 31 & 67 & 52 & 171 & 135 & 5 & 14 \\
\hline EB 17 & 210 & 7 & 152 & 19 & 13 & 10 & 271 & 47 & 5 & 5 \\
\hline EB 18 & 210 & 9 & 83 & 25 & 18 & 10 & 229 & 46 & 5 & 15 \\
\hline EB 19 & 119 & 7 & 205 & 27 & 34 & 33 & 240 & 87 & 5 & 5 \\
\hline EB 20 & 104 & 21 & 290 & 31 & 104 & 44 & 198 & 137 & 6 & 19 \\
\hline EB 21 & 192 & 9 & 160 & 28 & 40 & 27 & 190 & 94 & 5 & 12 \\
\hline EB 22 & 270 & 17 & 55 & 37 & 40 & 55 & 193 & 118 & 7 & 15 \\
\hline EB 23 & 186 & 8 & 260 & 29 & 72 & 54 & 217 & 154 & 5 & 11 \\
\hline EB 24 & 240 & 8 & 430 & 37 & 92 & 66 & 519 & 105 & 5 & 21 \\
\hline EB 25 & 240 & 11 & 180 & 34 & 44 & 38 & 878 & 110 & 6 & 40 \\
\hline EB 26 & 140 & 5 & 32 & 19 & 15 & 19 & 221 & 72 & 5 & 6 \\
\hline EB 27 & 145 & 7 & 230 & 24 & 60 & 35 & 176 & 131 & 6 & 5 \\
\hline EB 28 & 170 & 7 & 310 & 36 & 43 & 27 & 521 & 94 & 5 & 41 \\
\hline EB 29 & 120 & 5 & 250 & 28 & 75 & 108 & 220 & 75 & 5 & 5 \\
\hline
\end{tabular}


Table 3: Trace Element Analyses (ppm) at Western Bank, 305 Level (305 WA) of the

\begin{tabular}{|c|c|c|c|c|c|c|c|c|c|c|}
\hline S.N. & V & $\mathbf{C o}$ & $\mathbf{N i}$ & $\mathbf{C u}$ & $\mathbf{Z n}$ & $\mathbf{R b}$ & $\mathbf{S r}$ & $\mathbf{Z r}$ & $\mathbf{M o}$ & $\mathbf{P b}$ \\
\hline WA1 & 5 & 15 & 140 & 15 & 11 & 10 & 170 & 11 & 5 & 5 \\
\hline WA2 & 240 & 18 & 330 & 37 & 56 & 49 & 170 & 56 & 7 & 9 \\
\hline WA3 & 250 & 15 & 350 & 29 & 48 & 30 & 220 & 57 & 5 & 40 \\
\hline WA4 & 220 & 18 & 320 & 32 & 52 & 44 & 90 & 106 & 7 & 25 \\
\hline WA5 & 145 & 15 & 250 & 25 & 51 & 43 & 220 & 120 & 7 & 6 \\
\hline WA6 & 41 & 29 & 145 & 23 & 26 & 21 & 740 & 76 & 7 & 8 \\
\hline WA7 & 58 & 15 & 154 & 29 & 16 & 10 & 480 & 68 & 5 & 5 \\
\hline WA8 & 58 & 25 & 144 & 22 & 26 & 18 & 740 & 68 & 5 & 5 \\
\hline WA9 & 78 & 15 & 180 & 22 & 18 & 17 & 170 & 75 & 7 & 5 \\
\hline WA10 & 380 & 16 & 250 & 19 & 53 & 34 & 170 & 118 & 6 & 21 \\
\hline WA11 & 80 & 15 & 162 & 28 & 23 & 25 & 130 & 94 & 6 & 5 \\
\hline WA12 & 48 & 15 & 160 & 21 & 19 & 18 & 100 & 81 & 7 & 5 \\
\hline WA13 & 58 & 25 & 100 & 26 & 20 & 18 & 170 & 54 & 5 & 7 \\
\hline WA14 & 7 & 29 & 64 & 26 & 13 & 10 & 480 & 53 & 7 & 5 \\
\hline WA15 & 34 & 20 & 36 & 21 & 16 & 11 & 130 & 80 & 5 & 5 \\
\hline WA16 & 11 & 21 & 200 & 20 & 22 & 24 & 220 & 80 & 7 & 5 \\
\hline WA17 & 19 & 15 & 40 & 32 & 20 & 27 & 100 & 60 & 7 & 9 \\
\hline WA18 & 100 & 16 & 110 & 21 & 36 & 29 & 260 & 113 & 5 & 5 \\
\hline WA19 & 110 & 17 & 110 & 19 & 32 & 35 & 864 & 195 & 5 & 6 \\
\hline WA20 & 350 & 30 & 350 & 70 & 106 & 64 & 130 & 137 & 7 & 25 \\
\hline WA21 & 350 & 48 & 360 & 62 & 115 & 73 & 260 & 164 & 7 & 31 \\
\hline WA22 & 340 & 32 & 340 & 62 & 116 & 76 & 191 & 138 & 8 & 20 \\
\hline
\end{tabular}

Table 4: Trace Element Analyses (ppm) at Western Bank, 327 Level (327 WB) of the Lake $(n=14)$.

\begin{tabular}{|c|c|c|c|c|c|c|c|c|c|c|}
\hline & $\mathbf{V}$ & $\mathbf{C o}$ & $\mathbf{N i}$ & $\mathbf{C u}$ & $\mathbf{Z n}$ & $\mathbf{R b}$ & $\mathbf{S r}$ & $\mathbf{Z r}$ & Mo & Pb \\
\hline WB23 & 5 & 5 & 5 & 16 & 10 & 10 & 130 & 10 & 5 & 5 \\
\hline WB24 & 390 & 11 & 360 & 41 & 93 & 51 & 170 & 93 & 6 & 8 \\
\hline WB25 & 165 & 8 & 192 & 25 & 47 & 43 & 570 & 105 & 5 & 13 \\
\hline WB26 & 142 & 12 & 183 & 18 & 20 & 17 & 170 & 62 & 6 & 5 \\
\hline WB27 & 40 & 17 & 41 & 29 & 12 & 17 & 190 & 58 & 5 & 5 \\
\hline WB28 & 36 & 16 & 98 & 25 & 18 & 10 & 200 & 67 & 5 & 5 \\
\hline WB29 & 140 & 22 & 130 & 29 & 36 & 25 & 220 & 72 & 5 & 16 \\
\hline WB30 & 14 & 16 & 80 & 28 & 20 & 10 & 420 & 57 & 5 & 5 \\
\hline WB31 & 7 & 15 & 25 & 24 & 12 & 22 & 188 & 55 & 5 & 5 \\
\hline WB32 & 11 & 18 & 44 & 29 & 21 & 30 & 153 & 112 & 5 & 5 \\
\hline WB33 & 22 & 19 & 260 & 20 & 70 & 59 & 140 & 118 & 5 & 5 \\
\hline WB34 & 220 & 16 & 90 & 26 & 42 & 32 & 1300 & 115 & 5 & 24 \\
\hline WB35 & 280 & 18 & 305 & 50 & 106 & 72 & 170 & 140 & 6 & 31 \\
\hline WB36 & 300 & 20 & 345 & 34 & 120 & 83 & 189 & 141 & 5 & 36 \\
\hline
\end{tabular}

Examination of Table (5) reveals that vanadium (V) content at the eastern bank of the lake is higher at (305) level than that at (327) level, this is because the (305) level has remained submerged for longer period (18) months than the (327) level (6 
months). This means that more organic matter has accumulated at the (305) level and months). This meval of clay-size particles and the concentration of residual fraction. These processes have lead to more concentration of vanadium at the (305) level, compared with (327) level.

Table 5: Mean Values for the Analyses of Trace Elements (ppm) Within (305) and (327) (m.a.s.1.) Submergence Levels of the Recent Sediments of the Lake Compared with Unsubmerged Parts.

\begin{tabular}{|l|c|c|c|c|c|c|c|c|c|c|}
\hline $\begin{array}{l}\text { Sedimen } \\
\text { t }\end{array}$ & $\mathbf{V}$ & $\mathbf{C o}$ & $\mathbf{N i}$ & $\mathbf{C u}$ & $\mathbf{Z n}$ & $\mathbf{R b}$ & $\mathbf{S r}$ & $\mathbf{Z r}$ & Mo & Pb \\
\hline EA & 199 & 12 & 205 & 31 & 47 & 41 & 272 & 112 & 6 & 23 \\
\hline EB & 184 & 9 & 203 & 30 & 51 & 41 & 289 & 100 & 5 & 15 \\
\hline *EC & 140 & 7 & 152 & 20 & 29 & 23 & 303 & 80 & N.D. & 6 \\
\hline WA & 136 & 21 & 195 & 30 & 41 & 31 & 282 & 91 & 6 & 12 \\
\hline WB & 127 & 15 & 154 & 28 & 45 & 34 & 301 & 86 & 5 & 12 \\
\hline *WC & 100 & 9 & 150 & 24 & 35 & 24 & 345 & 70 & N.D. & 7 \\
\hline
\end{tabular}

EA: 305 level. Eastern Bank

EB: 327 level, Eastern Bank

EC: Unsubmerged Part, Eastern Bank

WA: 305 level, Western Bank

WB: 327 level, Western Bank; WC: Unsubmerged Part, Western Bank

N.D.: Not Detected

*: From Al-Kawaz, 1991

Similar situation exist at the western bank at both (305) and (327) levels, but to a lesser extent (Tables 5 and 6 ) due to the steeper slope at this bank, which means lesser area is exposed to submergence. The steep slope may cause the sliding of large masses of rocks into the water, leading to a continual exposure of fresh surfaces under the effects of the aforementioned factors, and hence a relative decreases in their effects.

Because of the rather low concentrations of $(\mathrm{Co}),(\mathrm{Mo})$ and $(\mathrm{Pb}$ at eastern bank), the discussion of their behavior under submergence is not very reliable.

The trace elements $(\mathrm{Co})$ and $(\mathrm{Ni})$ at the eastern bank; $(\mathrm{Cu}),(\mathrm{Rb})$ and $(\mathrm{Mo})$ at both banks and $(\mathrm{Pb})$ at the western bank, show an increase in their concentrations due to submergence relative to the unsubmerged part (Table 5). However, the increase at (305) level either equal to ( $\mathrm{Rb}$ and $\mathrm{Pb}$ ) or slightly more than at (327) level.

Table 6: Percentage Increase or Decrease in Trace Elements at the Four Submerged Levels Relative to the Unsubmerged Part (in Table 5).

\begin{tabular}{|c|c|c|c|c|}
\hline Element & $\mathbf{3 0 5} \mathbf{E}(\mathbf{A})$ & $\mathbf{3 2 7} \mathbf{E}(\mathbf{B})$ & $\mathbf{3 0 5} \mathbf{W}(\mathbf{A})$ & $\mathbf{3 2 7} \mathbf{~ W ( B )}$ \\
\hline $\mathrm{V}$ & $42.1 \%$ & $31.4 \%$ & $36.0 \%$ & $27.0 \%$ \\
\hline $\mathrm{Co}$ & 71.4 & 28.6 & 133.3 & 66.7 \\
\hline $\mathrm{Ni}$ & 34.9 & 33.6 & 30.0 & 2.7 \\
\hline $\mathrm{Cu}$ & 10.7 & 7.1 & 25.0 & 16.7 \\
\hline $\mathrm{Zn}$ & 62.1 & 75.9 & 17.0 & 28.6 \\
\hline $\mathrm{Rb}$ & 78.3 & 78.3 & 29.2 & 41.7 \\
\hline $\mathrm{Sr}$ & -10.2 & -4.6 & -18.3 & -12.8 \\
\hline $\mathrm{Zr}$ & 40.4 & 25.0 & 30 & 23 \\
\hline $\mathrm{Mo}$ & $\mathrm{X} 6(600 \%)$ & $\mathrm{X} 5$ & $\mathrm{X} 6$ & $\mathrm{X} 5$ \\
\hline $\mathrm{Pb}$ & 283 & 150 & 71.4 & 71.4 \\
\hline
\end{tabular}


It is possible that each of these elements is present in at least two mineral phases (clay minerals and heavy fraction), in almost equal amounts. The decrease in their concentrations due to the removal of clay size particles is counter balanced by the increase in concentration of the heavy fraction, including the sulphide phase.

At the western bank and at (305) level, (Ni) shows a marked increase (195pm) among these elements compared with the (327) level $(154 \mathrm{ppm})$ and with unsubmerged part $(150 \mathrm{ppm})$. It is possible that $(\mathrm{Ni})$ is concentrated within the sulphide phase more than within the clay minerals which are continually removed due to successive and longer submergence of (305) level relative to (327) level.

Zinc $(\mathrm{Zn})$ unlike the rest of elements shows a decrease in its concentration at (305) levels of both banks. This is possibly due to its presence in the carbonate phase (dolomite), which has been subjected to dissolution at (305) level more than at (327) level due to longer submergence of the (305) level.

Strontium ( $\mathrm{Sr}$ ) is the only element that shows a marked decrease in its concentration at both levels and at both banks and the decrease is more at (305) level (Tables 5 and 6). It is clear that the decrease in ( $\mathrm{Sr}$ ) is due to the dissolution of the relatively soluble phases of carbonates (calcite and dolomite) and sulphates (gypsum), where ( $\mathrm{Sr}$ ) substitutes for calcium $\left(\mathrm{Ca}^{2+}\right)$ in these phases. The longer submergence period of the (305) level causes more ( $\mathrm{Sr}$ ) to be dissolved at this level.

Zirconium $(\mathrm{Zr})$ exhibits a marked increase at both (305) and (327) levels and at both eastern and western banks. The increase is more at (305) level (Table 5). It is well known that zirconium in sedimentary rocks is concentrated in the heavy mineral zircon $\left(\mathrm{ZrSiO}_{4}\right)$. The longer the submergence period, the more fine grained fraction is removed, which means the more is the concentration of the heavy fraction

The percentage increase of $(\mathrm{Zr})$ at (305) level at both banks (east and west ( $40 \%$ east), and ( $30 \%$ west) is more than that at (327) level ( $25 \%$ east) and ( $23 \%$ west). This is due to longer submergence period at the (305) level than the (327) level.

At the eastern bank, the element lead (Pb) shows an increase at both (305) and (327) levels being more at the (305) level (Table 5). This means that $(\mathrm{Pb})$ is mainly concentrated within the heavy fraction, the sulphide phase at this bank.

From the foregoing discussion, it seems that there are four patterns of variation in the concentrations of the studied trace elements in the recent sediments of Mosul lake; these are: (a) Increase in their contents at both (305) and (327) levels; the increase being more at the (305) level (V, Co and $\mathrm{Pb}$ at the eastern bank only) (b) Increase at both (305) and $(327)$ levels; the increase being less at $(305)$ level $(\mathrm{Zn})(\mathrm{c})$ Increase at both levels at equal or almost equal amounts $(\mathrm{Ni}, \mathrm{Cu}, \mathrm{Rb}, \mathrm{Mo}$ and $\mathrm{Pb}$ at the western bank) and (d) decrease at both levels $(\mathrm{Sr})$.

Inter-element correlation matrices for (305) and (327) levels at both eastern and western banks (Tables 7, 8, 9 and 10) confirms the pattern of distributions of the ten trace elements discussed above.

The elements that show an increase in their concentrations at the (305) or (327) level exhibit positive correlations between them. For example, at the eastern bank and at (305) level (Table 7), vanadium (V) positively correlates with (Co, $\mathrm{Ni}, \mathrm{Cu}, \mathrm{Zn}, \mathrm{Rb}, \mathrm{Zr}$, $\mathrm{Mo}$, and $\mathrm{Pb}$ ). All these elements exhibit an increase in their concentrations at (305) level, compared with the unsubmerged part of the sediment (Table 5). 
On the other hand, these elements show negative correlation with $(\mathrm{Sr})$ which shows decrease in its concentration at the (305) level ( and at 327 level). Similar relationship hold for most of these trace elements in the other three tables (Tables 8,9 and 10).

Table 7: Correlation Coefficient Matrix for the Trace Elements, 305 level, Eastern Bank ( $n=15)$.

\begin{tabular}{|} 
Bank $(\mathrm{n}=15)$ \\
\begin{tabular}{|c|c|c|c|c|c|c|c|c|c|c|}
\hline & $\mathbf{V}$ & $\mathbf{C o}$ & $\mathbf{N i}$ & $\mathbf{C u}$ & $\mathbf{Z n}$ & $\mathbf{R b}$ & Sr & $\mathbf{Z r}$ & Mo & Pb \\
\hline $\mathrm{V}$ & 1.00 & & & & & & & & & \\
\hline $\mathrm{Co}$ & 0.43 & 1.00 & & & & & & & & \\
\hline $\mathrm{Ni}$ & 0.82 & 0.48 & 1.00 & & & & & & & \\
\hline $\mathrm{Cu}$ & 0.73 & 0.03 & 0.66 & 1.00 & & & & & & \\
\hline $\mathrm{Zn}$ & 0.90 & 0.60 & 0.87 & 0.74 & 1.00 & & & & & \\
\hline $\mathrm{Rb}$ & 0.72 & -0.2 & 0.51 & 0.01 & 0.54 & 1.00 & & & & \\
\hline $\mathrm{Sr}$ & -0.20 & -0.35 & -0.25 & -0.50 & -0.26 & -0.58 & 1.00 & & & \\
\hline $\mathrm{Zr}$ & 0.49 & 0.46 & 0.24 & 0.01 & 0.34 & 0.84 & -0.11 & 1.00 & & \\
\hline $\mathrm{Mo}$ & 0.47 & 0.54 & 0.44 & 0.61 & 0.45 & 0.61 & -0.13 & 0.46 & 1.00 & \\
\hline $\mathrm{Pb}$ & 0.49 & 0.03 & 0.72 & 0.01 & 0.54 & 0.01 & 0.65 & 0.01 & -0.02 & 1.00 \\
\hline
\end{tabular}
\end{tabular}

Table 8: Correlation Coefficient Matrix for the Trace Elements, 327 level, Eastern

\begin{tabular}{|c|c|c|c|c|c|c|c|c|c|c|}
\hline & V & Co & $\mathrm{Ni}$ & $\mathrm{Cu}$ & $\mathrm{Zn}$ & $\mathrm{Rb}$ & $\mathrm{Sr}$ & $\mathrm{Zr}$ & Mo & $\mathrm{Pb}$ \\
\hline $\mathrm{V}$ & 1.00 & & & & & & & & & \\
\hline $\mathrm{Co}$ & 0.05 & 1.00 & & & & & & & & \\
\hline $\mathrm{Ni}$ & 0.70 & 0.11 & 1.00 & & & & & & & \\
\hline $\mathrm{Cu}$ & 0.56 & 0.09 & 0.75 & 1.00 & & & & & & \\
\hline $\mathrm{Zn}$ & 0.47 & 0.36 & 0.79 & 0.70 & 1.00 & & & & & \\
\hline $\mathrm{Rb}$ & 0.39 & 0.0 & 0.51 & 0.73 & 0.69 & 1.00 & & & & \\
\hline $\mathrm{Sr}$ & -0.52 & -0.31 & -0.54 & -0.29 & -0.26 & -0.23 & 1.00 & & & \\
\hline $\mathrm{Zr}$ & 0.64 & $=0.02$ & 0.26 & 0.07 & 0.01 & -0.02 & 0.13 & 1.00 & & \\
\hline Mo & 0.13 & 0.73 & -0.06 & -0.10 & 0.13 & 0.10 & 0.09 & 0.07 & 1.00 & \\
\hline $\mathrm{Pb}$ & 0.46 & 0.31 & 0.67 & 0.83 & 0.40 & 0.49 & -0.18 & 0.22 & 0.22 & 1.00 \\
\hline
\end{tabular}

Table 9: Correlation Coefficient Matrix for the Trace Elements, 305 Level,

\begin{tabular}{|c|c|c|c|c|c|c|c|c|c|c|}
\hline Western Bank $(\mathrm{n}=22)$. \\
\hline $\mathbf{V}$ & $\mathbf{V}$ & $\mathbf{C o}$ & $\mathbf{N i}$ & $\mathbf{C u}$ & $\mathbf{Z n}$ & $\mathbf{R b}$ & $\mathbf{S r}$ & $\mathbf{Z r}$ & $\mathbf{M o}$ & $\mathbf{P b}$ \\
\hline $\mathrm{V}$ & 1.00 & & & & & & & & & \\
\hline $\mathrm{Co}$ & 0.33 & 1.00 & & & & & & & & \\
\hline $\mathrm{Ni}$ & 0.92 & 0.36 & 1.00 & & & & & & & \\
\hline $\mathrm{Cu}$ & 0.72 & 0.63 & 0.78 & 1.00 & & & & & & \\
\hline $\mathrm{Zn}$ & 0.89 & 0.59 & 0.86 & 0.89 & 1.00 & & & & & \\
\hline $\mathrm{Rb}$ & 0.30 & -0.12 & 0.44 & 0.17 & 0.16 & 1.00 & & & & \\
\hline $\mathrm{Sr}$ & -0.26 & -0.45 & -0.33 & -0.28 & -0.23 & -0.10 & 1.00 & & & \\
\hline $\mathrm{Zr}$ & 0.63 & 0.44 & 0.50 & 0.52 & 0.70 & -0.11 & -0.02 & 1.00 & & \\
\hline $\mathrm{Mo}$ & 0.51 & 0.52 & 0.46 & 0.67 & 0.71 & -0.01 & 0.07 & 0.45 & 1.00 & \\
\hline $\mathrm{Rb}$ & 0.80 & 0.30 & 0.85 & 0.06 & 0.70 & 0.68 & -0.26 & 0.35 & 0.33 & 1.00 \\
\hline
\end{tabular}


Table 10: Correlation Coefficient Matrix for the Trace Elements, 327 Level, Western Bank $(n=14)$.

\begin{tabular}{|c|c|c|c|c|c|c|c|c|c|c|}
\hline & $\mathbf{V}$ & $\mathbf{C o}$ & $\mathbf{N i}$ & $\mathbf{C u}$ & $\mathbf{Z n}$ & $\mathbf{R b}$ & $\mathbf{S r}$ & $\mathbf{Z r}$ & $\mathbf{M o}$ & $\mathrm{Pb}$ \\
\hline $\mathrm{V}$ & 1.00 & & & & & & & & & \\
\hline $\mathrm{Co}$ & 0.92 & 1.00 & & & & & & & & \\
\hline $\mathrm{Ni}$ & 0.71 & 0.53 & 1.00 & & & & & & & \\
\hline $\mathrm{Cu}$ & 0.92 & 0.49 & 0.68 & 1.00 & & & & & & \\
\hline $\mathrm{Zn}$ & 0.81 & 0.65 & 0.89 & 0.82 & 1.00 & & & & & \\
\hline $\mathrm{Rb}$ & 0.68 & 0.67 & 0.83 & 0.72 & 0.95 & 1.00 & & & & \\
\hline $\mathrm{Sr}$ & -0.23 & -0.19 & 0.00 & 0.13 & -0.01 & -0.02 & 1.00 & & & \\
\hline $\mathrm{Zr}$ & 0.58 & 0.72 & 0.69 & 0.65 & 0.76 & 0.86 & 0.23 & 1.00 & & \\
\hline $\mathrm{Mo}$ & 0.62 & 0.39 & 0.45 & 0.52 & 0.62 & 0.57 & -0.18 & 0.36 & 1.00 & \\
\hline $\mathrm{Rb}$ & 0.68 & 0.83 & 0.49 & 0.72 & 0.75 & 0.75 & 0.34 & 0.70 & 0.53 & 1.00 \\
\hline
\end{tabular}

\section{CONCLUSIONS}

1. There are four trends of variation in the concentrations of the studied ten trace elements, in the submerged sediments relative to the unsubmerged; these are: (a) Increase at both (305) and (327) levels; the increase being more at the (305) level (V, $\mathrm{Co}, \mathrm{Zr}$ and $\mathrm{Pb}$ ); (b) Increase at both (305) and (327) levels. The increase being less at (305) level $(\mathrm{Zn})$. (c) Increase at both (305) and (327) levels at equal or almost equal amounts $(\mathrm{Ni}, \mathrm{Cu}, \mathrm{Rb}, \mathrm{Mo}$ and $\mathrm{Pb}$ at the western bank) and (d) decrease a both levels $(\mathrm{Sr})$.

2. There are four factors affecting the distribution of trace elements within the submerged sediments of Mosul lake; these are: dissolution of relatively soluble mineral phases (carbonates and sulphates); mechanical removal of clay-size particles; addition of organic matter; and the slope of the submerged sediments and surrounding rocks.

\section{REFERENCES}

Aljubouri, Z.A.J., 1972. Geochemistry, Origin and Diagenesis of Some Triassic Gypsum Deposits and Associated Sediments in the East Midlands, England. Unpublished Ph.D. Thesis, University. Of Nottingham, England, U.K.

Aljubouri , Z.A.J., Al-Kattan, M. and Al-Sayegh, A.Y. 1994. Geochemistry, Mineralogy and Colour of Gercus Formation at Zawita, Iraq Africa Geoscience Review, 1(4), pp.547-556.

Aljubouri, Z.A.J. and M.D. Sulayman, 1996. Mineralogy and Geochemistry of Gypsum Rocks of Al-Fath'a Formation at West Butma Area, Northern Iraq. Raf. Jour. Sci., 7(1), pp.114-128.

Al-Kawaz, H.A.M., 1991. The effects of Erosion on the Geochemical and Mineralogical Variations of the Recent Sediments, within Submerged Part of Mosul Lake: Confidential. Mosul Research Centre for Dams and Water Resources. University of Mosul, Iraq. (In Arabic).

Al-Naqib, S. Q, and Th. M. Al-Taiee, 1988. The Effect of Suspended Sediment load, Transported from Fayda and Buqak Wadies, on Mosul Lake as related to Watershed Characteristics. Confidential Mosul Dam Research Centre, University. of Mosul, Iraq. 
Al-Rawi, S.M., Mustafa, M.M. and Al-Kawaz, H.A.M., 1990. A Study of the Pollution in Duhok Valley and its Impact Upon Mosul Lake Water Quality. Mosul Dam Research Centre. Mosul University, Mosul, Iraq, Confidential,

Al-Ubaidi, S.A., 1984. Geochemistry, Mineralogy and Petrography of the Argillaceous Carbonate Rocks of the Fat'ha Formation at Butma West Area. Unpubl. M.Sc. Thesis, University. of Mosul, Iraq.

Degens, E.T., 1965. Geochemistry of Sediments: A Brief Survey; Prentice Hall, New Jersey, U.S.A. 420 p.

Goldschmidt, V.M., 1954. Geochemistry, Clarenden Press, London.

Hirst. D.M., 1962. The Geochemistry of Modern Sediments from the Gulf of Paria. Geochim Cosmochim Acta., 6, pp.309-334.

Kraushopf, K.B., 1967. Introduction to Geochemistry; McGraw Hill, London, 620p.

Mason, B., 1966: Principles of Geochemistry; $3^{\text {rd }}$ Edition, John Wiley, New York, 330p.

Nicholls, G.D. and D.H. Loring, 1962. The Geochemistry of Some British Carboniferous Sediments. Geochim Cosmochim Acta., 26, pp.181-223.

Norrish, K. and B.W. Chappel, 1967. X-ray fluorescence Spectroscopy. In ; Zussman, J. (Ed) : Physcial methods in Determinative Mineralogy, p. 161-214; Academic Press, London.

Tenyakov, V.A., 1965. The Geochemistry of Vanadium in Bauxite. Geochemistry, 10, 553.

Turkian, K.K. and J. L. Kulp, 1956. The Geochemistry of Strontium. Geochim. Cosmochim. Acta; 10, pp.245-296.

Vlasov, K.A., 1964. Geochemistry of Rare Metals : Palestinian program for Scientific Translation; Jerusalem, 1966. 